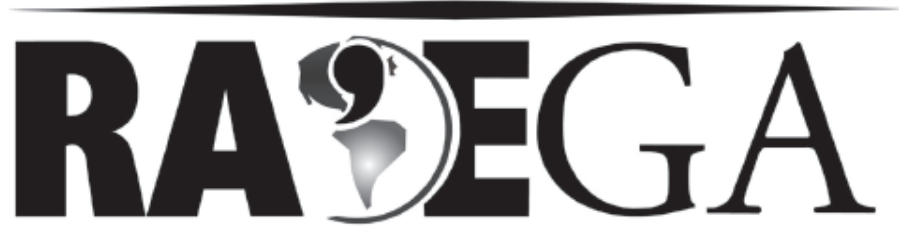

O ESPAÇO GEOGRÁFICO EM ANÁLISE

\title{
INDIGNADOS COM O MUNDO, TRANSTORNADOS COM \\ O INSTITUCIONALISMO: A GEOGRAFIA DO UNDERGROUND CRISTÃO BRASILEIRO NA ERA PÓS- SECULAR E PÓS-CRISTÃ
}

\author{
OUTRAGED WITH THE WORLD, UPSET BY \\ INSTITUTIONALISM: THE GEOGRAPHY OF BRAZILIAN \\ CHRISTIAN UNDERGROUND IN THE POST-CHRISTIAN \\ AND SECULAR ERA
}

Diogo da Silva Cardoso ${ }^{1}$

\section{Resumo}

Este artigo é uma continuidade das reflexões já em curso sobre o underground cristão, novo movimento religioso de cariz juvenil que tem como suporte social e estético a atuação performática a partir da arte e da cultura secularizadas (hip-hop, heavy metal, indie, clubber, punk). Adotando um estilo de vida pósmoderno, esses jovens cristãos "descolados" buscam meios de se inserir nas redes jovens do cotidiano social e, em certa medida, se autopromover tanto na comunidade eclesial como nas cenas artísticas independentes (underground, por exemplo). Entender os motivos e implicações dessas novas comunidades confessionais é entender a nova dinâmica religiosa que perfaz a religiosidade juvenil pós-moderna, onde o cosmopolitismo e a estetização são as palavras de ordem, itens obrigatórios do indivíduo assecla e do território religioso alternativo que intenta ser uma heterotopia, isto é, um espaço que carrega as

\footnotetext{
${ }^{1}$ Doutorando pelo Programa de Pós-Graduação em Geografia da Universidade Federal do Rio de Janeiro - UFRJ, Bolsista CAPES. Professor da rede pública do Estado do Rio de Janeiro. Tutor a distância do LANTE/UFF. Rio de Janeiro, RJ, Brasil. diogo georeg@yahoo.com.br
} 
marcas de um mundo em profunda mudança, onde o não-diálogo com o extramuros é considerado heresia e qualquer forma de pensar e agir não que não seja jovem é tido como obsoleto.

Palavras-chave: underground cristão; juventude; religiosa; pós-secular; comunidades de afeto e sentido; gêneros musicais alternativos.

\section{Abstract}

This article is a continuation of reflections on the Christian underground, new youth-oriented religious movement that is supported by the social and aesthetic performative action from the secular art and culture (hip-hop, heavy metal, indie, clubber, punk). Adopting a postmodern lifestyle, these young Christians "funky" looking for ways to insert themselves in the everyday social youth networks and to some extent, promote itself both in the church community as the independent art scene (underground, for example). Understanding the reasons and implications of this new faith communities is to understand the new dynamic that makes religious in postmodern youths, where cosmopolitanism and aestheticism are the slogans, the individual items required minion and alternative religious territory that tries to be a heterotopia, i.e. a space that bears the marks of a world undergoing profound change, where the non-dialogue with the extramural is considered heresy and any form of thinking and acting is not that young man is considered obsolete.

Keywords: Christian underground; religious youth; post-secular; communitybased in affect and feeling; alternative musical genres.

\section{Introdução}

Entregues à "loucura" de fazer e viver o Evangelho com atitude, de maneira plena e radiante. Eis o quadro das novas juventudes cristãs que estão no turbilhão das mudanças sociorreligiosas nos centros e periferias das cidades brasileiras. Seja na rua, praça, coreto ou galpão semiabandonado, ou ainda, nos púlpitos e corredores das denominações evangélicas, o que as novas gerações desejam, na onda do midiatismo e do consumo cultural, são duas coisas: protagonismo e afirmação identitária.

Através da arte e de uma cultura de oposição (nova ecologia eclesiástica?), anseiam "agradar o Pai" e os seus pares, buscando sempre indicadores e indícios de mudança tanto na vida social quando nos recônditos eclesiásticos. Estamos falando aqui de um cristianismo que, ocidentalizado desde a sua base, jaz em permanente transformação em alguns de seus elementos mais essenciais (liturgia, proselitismo, adoração, conduta de vida), 
com repercussões claras e diretas no setor das mídias e da cultura visual, onde as transformações, mais que evidentes, apontam, conforme o discurso nativo de vários teólogos, para um cenário cristão permeado pelos "pós": pósocidental, pós-moderno, pós-colonial ou mesmo pós-cristão (KIMBALL, 2008). Com quem eles interagem e costuram alianças? Como boa parte do segmento evangélico, ignoram os católicos ${ }^{2}$; falam "poucas e boas" dos funkeiros, mas se rendem a qualquer estilo artístico e visual que remeta a uma minoria étnica, estilo cultural ou comunidade que faça contraponto ao cristianismo dominante, ou legalismo que tem feito a "Igreja" estar cada vez mais intimamente associado ao sistema capitalista "mundano"3.

Eis o que é o underground cristão:

1. Um movimento contracultural cuja marca identitária é o protesto (CARSON, 2010), a crítica zombeteira ${ }^{4}$ ao legalismo institucional e a rebelião espiritualizada com o uso amplo, e por vezes obsessivo, das artes-culturas seculares;

2. Uma identidade plástica, transitiva e que ressoa numa comunidade imaginada (ANDERSON, 1987); possui uma dinâmica, liderança, ritualidade e senso de pertença muito específicos conforme o lugar ou região de atuação do grupo;

3. Propõe uma ressemiologização do cristianismo ocidental via protagonismos mediados pelos grupamentos juvenis urbanos secularizados ${ }^{5}$;

\footnotetext{
${ }^{2}$ Uma das raras exceções é o Manifesto Missões Urbanas de Uberlândia (MG), cujo pastor Ariovaldo Junior, numa entrevista pessoal concedida em 2009, disse que o diálogo com os católicos "de mente aberta" não é só bem-vindo, como se faz necessário.

${ }^{3}$ Ao longo do texto usarei entre aspas frases comumente pronunciadas pelos cristãos undergrounds, tanto como forma de dar voz a eles quanto de romper com a indolência da Ciência e colocá-la em diálogo com o senso comum crítico-emancipatório (SANTOS, 2001).

${ }^{4}$ Vide o sarcástico blog <http://www.genizahvirtual.com/> Acessado em: 4 mai. 2012, bastante utilizado por alguns undergrounds para apoiar o discurso crítico que fazem do institucionalismo evangélico e da primazia da liturgia sobre o convívio em comunidade.

5 Em todo o texto, optarei por não utilizar a já consagrada expressão "culturas juvenis", pois assim como Varela (2008), entendo que a cultura juvenil é um sintagma equivocado, pois não alude às opções e escolhas que o jovem tem e pode hibridizar, não aderindo necessariamente a uma única vertente de ação coletiva juvenil. Um adepto da música hip hop pode muito bem frequentar baile funk, ir aos domingos em uma igreja católica e se articular com fãs de rock e heavy metal. Tudo é uma questão de opções de bens culturais a serem escolhidas pelo jovem, não necessariamente podemos categorizar um gênero musical ou um estilo visual como sendo uma cultura urbana, um motivo de fusão de jovens em uma comunidade de estilo e sentido; e tampouco podemos enquadrar o jovem dentro de um padrão cultural - tais classificações podem até ter validade nas análises da contracultura de 1960-70, quando o hippie era
} 
4. É uma fusão gregária de subestilos artísticos com o fito de chamar atenção, "chocar", enfim, realizar a Missão por meios legitimamente culturais, sendo a arte o principal veículo de mensagem;

5. Há um gosto especial pelos subgêneros musicais alternativos, sendo o rock e o heavy metal os que inauguraram o movimento no Brasil (CARDOSO, 2011) e se destacam hoje nas mídias e nas comunidades de crença underground. É visto por muitos como os estilos que dão autenticidade ao movimento, sendo os outros (funk, pop rock, emo, metalcore) uma mera roupagem do que é proferido pela indústria cultural massiva;

6. Partilham teologias pós-modernas, donde a aceitação da pluralidade cultural e da negociação de discursos é um objetivo a ser perseguido pelos cristãos neoreformados; características fundantes, sendo que em alguns contextos (europeu, australiano e norte-americano, principalmente), tem se firmado um estilo de pensamento subversivo que confirma as predições de um cenário cristão secularizado.

Da metrópole à cidade diminuta, onde houver um headbanger, punk, rapper ou "modista" vagueando pelas ruas com um fone de celular no ouvido e uma garrafa de cerveja na mão, ali estará dada a condição socioespacial ou para a instalação de uma comunidade underground, ou para a atuação de um único prosélito que seja, mas que tem sede de triunfar na carreira missionária, seguindo o leitmotiv teológico do apóstolo Paulo: "Temos que combater o bom combate, para completar a carreira e guardar a fé" (BÍBLIA, $2^{\circ}$ Timóteo 4:7).

Como veremos nos próximos itens, essa cultura religiosa que muitos chamam de underground cristão pertence a um movimento mais amplo chamado Igreja Emergente (que não é mais tão emergente assim, pois já se faz 20 anos que estão emergindo!), que se trata de um braço sociocultural de todo um processo que, numa ponta, tem formado uma geração de evangélicos não-praticantes, e na outra, um montante de pessoas que se auto-intitulam 
"sem-religião". No caso dos undergrounds, a linha que os separa entre praticantes e não-praticantes é tão tênue que só por meio de uma participação não-desengajada o pesquisador (CARDOSO, 2011; MONDADA \& SODERSTROM, 2004), pode-se entender o que, de fato, os atrai para essas novas comunidades emocionais e, por outro lado, coloca-os em uma situação de relativo descaso (e indiferença) com as outras instituições e religiosidades. Esse processo está embutido dentro da modernidade ocidental que tende a levar todas as religiões e religiosidades a uma situação inusitada e perigosa: da religião ser engolida pelas culturas seculares ou, ao contrário, dela se reconectar com o mundo da vida sem grandes perdas psicológicas ou de sacralidade, mantendo assim a composição do poder religioso (igreja e suas estruturas administrativas e educativas) sem acarretar na perda do numinoso ottoniano que tão bem faz da religião uma armação sociocultural diferente dos outros modos de sociação humana.

\section{Um atalho antes de chegar ao underground cristão: compreendendo o campo cristão brasileiro}

Mudanças significativas vêm acontecendo no campo cristão brasileiro, isso é notório e não é algo novo. No entanto, são mudanças que estão para além da liturgia e do diálogo inter-religioso: trata-se de mudanças na base ontológica da vida religiosa dos fiéis e de uma mudança nas estruturas de poder e gestão religiosa. Um exemplo de mudança significativa tem ocorrido nas denominações protestantes e pentecostais, até mesmo na Assembléia de Deus, denominação reconhecida pela rigidez doutrinária e pela observância radical dos usos e costumes da membresia.

A Assembléia de Deus, conhecida por ter em sua composição eclesiástica um público de origem humilde, inculta e bastante rígida com relação ao uso de vestes, falas, gestos e dons espirituais, vêm vagarosamente se abrindo para novos horizontes. Sua estrutura administrativa é, em grande parte, politicamente descentralizada e territorialmente "desregulada", dada a alta flexibilidade existente na formação de pontos de pregação e de pequenas 
comunidades, e na falta de dados consistentes sobre o perfil da membresia. Hoje, as Assembléias buscam inspiração em outras denominações para estabelecer níveis de hierarquização e de administração seguros para gerir esta que se tornou a maior denominação pentecostal do país. Sobre isso, Mafra indica que:

O contraste com a sistematicidade, racionalidade organizacional e baixo personalismo que os Batistas imprimem no seu meio é grande, e vários líderes assembleianos vão buscar na denominação irmã inspiração "administrativa" para superar os problemas que enfrentam no seu dia-a-dia. Preocupa o fato, por exemplo, de a Convenção de São Cristóvão reunir cerca de 5 mil membros, em 80 congregações, sem que se consiga agregar as informações de dados censitários ou do aproveitamento das alternativas que estão sendo experimentadas em cada nicho. As informações que circulam são necessariamente filtradas pelo pastor presidente de cada congregação. (MAFRA, 2001, p.67).

A par do que falamos até aqui, passaremos agora a destacar a formação, no Brasil, desde as décadas de 70 e 80 do século passado, de uma "nova" juventude cristã evangélica e alternativa, juventude esta que vem engendrando variações e transformações significativas tanto no escopo proselitista como na própria geografização do campo religioso.

Baseada em éticas e estéticas diametralmente opostas à ordem do discurso e das práticas que então vigoravam nas denominações tradicionais, esses grupos juvenis emergentes, muitos deles dissidentes de igrejas evangélicas, promulgaram a rejeição a quaisquer formas de puritanismo como o cometido pelas gerações anteriores.

A crítica feita pelos jovens cristãos radicais ao sistema religioso cristão como um todo, assim como a re-invenção de símbolos, comportamentos, discursos e atitudes por estes, só se tornou possível mediante a assimilação de ideias, objetos, comportamentos e outras tendências advindas da cultura secular de massas.

Neste ponto, a dialética entre o ser e o vir-a-ser tomou diversas direções, formas e conteúdos que evidenciaram as contradições em vários 
lados da situação. Podemos dividir essas contradições entre os grupos da seguinte maneira:

1. De um lado, houve medo, austeridade e uma tendência ao fechamento ideológico por parte daqueles que exercem o poder sagrado e que controlam a produção de bens de salvação. Muitas igrejas estão, inclusive, propondo novos fundamentalismos para suas igrejas a fim de não perderem a sua essência religiosa e, mais ainda, perder fiéis para o neopentecostalismo e para as comunidades alternativas. Batista, Presbiteriana e Metodista são as igrejas que mais vem sofrendo perda quantitativa de fiéis, e são as que mais se fundamentalizaram nos últimos anos ${ }^{6}$;

2. Em segundo lugar, temos os membros leigos, avessos às inovações e desafios, mas que, de repente, viram-se frente a novas questões e afrontamentos do tipo: "como aceitar esses jovens rebeldes em nossa igreja?", "será que podem usar tatuagem, piercing e essas outras coisas exóticas sem se corromperem com Deus?", "o rock é maligno? Ou pode ser usado para evangelizar?", "Deus está presente nessas manifestações”? Dentre tantos outros questionamentos;

3. E por fim, o sentimento de "quero mais", de "não estamos satisfeito com o que aí está", ou do "não queremos partilhar dos mesmos costumes", presente em parcela considerável da juventude (cristã ou não) aturdida com a falta de sentido que marca as sociedades ocidentais desde a metade do século passado.

Podemos perceber que os evangélicos e os neopentecostais, juntos, configuram um campo religioso aberto, fluido, flexível, reflexivo (em parte), mas também tradicionalista, ascético (para os evangélicos), anti-radical e anti-

\footnotetext{
${ }^{6}$ Para essa questão, ver, dentre outros, o trabalho de Souza (2009) sobre o fundamentalização da Igreja Presbiteriana do Brasil.
} 
socialista, que aponta para a indiferença com relação aos problemas e injustiças sociais e ambientais ${ }^{7}$.

Jungblut (2007) fornece um embasamento teórico a respeito das mudanças no campo evangélico/neopentecostal. Estes, atualmente, vêm propagando a "desinterdição" de várias fronteiras simbólicas entre "Igreja" e a sociedade e o Estado seculares. Antigos dogmas são obliterados, enquanto outros surgem. Exemplo: com a profusão da sexualidade nas mídias e nos setores de atuação da juventude, a saída de muitas comunidades evangélicas foi apelar para o "namoro de corte", uma espécie de neopuritanismo onde um casal de namorados não pode se beijar e muito menos fazer sexo. Isso tudo, seguindo rigorosamente os "preceitos bíblicos", só pode ocorrer depois do casamento ${ }^{8}$.

Mas, em todo o caso, os cristãos podem agora dialogar, com cautela e zelo, diga-se de passagem, com as distintas áreas da mundanidade. A política é o caso mais concreto dessa realidade no Brasil, e no Sudeste, inúmeros líderes carismáticos galgaram postos de comando e influência econômica após a abertura dos templos para o extramuros.

Este processo vem se dando ora de forma frenética, ora "arrastada", mas independentemente da velocidade e intensidade das mudanças, o processo está em andamento, e tende a se tornar mais complexo, estruturado e saraivado de conflitos e disputas simbólicas:

[...] ao se tornar uma grande minoria religiosa, esse grupo, antes organizado em pequenas comunidades de crentes, foi perdendo sua capacidade de impor regras comportamentais restritivas, sobretudo nas igrejas que, em seus templos, passaram a realizar os cultos espetaculares de massa; ao diversificar-se institucionalmente e socialmente, passou a abranger cada vez mais segmentos de classe média, que, em geral, são pouco afetivos a condutas rigoristas e puritanas. [...] Com isso, eles vão se tornando cada vez mais indistintos da cultura e sociedade envolventes. Pode-se dizer que [...] vigora como que uma inusitada, e aparentemente paradoxal, fascinação de muitos evangélicos pela mundanidade que os

\footnotetext{
${ }^{7}$ Salvo algumas iniciativas e entidades que tentam conciliar espiritualidade com ação social, a exemplo da Koinonia (RJ), do SEOP (RJ), do CESE (BA), da Fundação Luterana de Diaconia (RS), da RENAS (SP), do Centro Cultural Jerusalém (RJ) etc.

${ }^{8}$ Essa polêmica é apresentada em inúmeros blogs, dentre eles: <http://evangelizacaopessoal.com/estudo12.html> Acessado em: 02 abr. 2012.
} 
envolve. Fascinação que se expressa por certa avidez em se apropriar de tudo aquilo que, produzido para finalidades mundanas ou não-religiosas, mostra-se simbólica e esteticamente sedutor, mobilizador de atenções, consumível em grande escala, racionalizador de esforços. (JUNGBLUT, 2007, p. 144-145).

Diante de tal fato, Geraldo Luiz Silva, pastor da comunidade Caverna de Adulão (MG) e professor de contracultura das agências missionárias Tribal Generation (MG) e Avalanche Missões Urbanas (ES), fez a seguinte declaração à Tribal Generation Magazine:

A igreja [convencional] tornou-se evangélica e deixou de ser protestante. Jesus fala que bem aventurado é aquele que tem sede de justiça. A grande parte das igrejas, se sentindo bem, se sentindo confortáveis consigo mesmas, tornaram-se insensíveis às injustiças do mundo. [...] A igreja brasileira vestiu todo o pensamento neoliberal como uma luva. Não há um entendimento ou uma insatisfação com 0 que está acontecendo lá fora. Há uma falsa espiritualização como se aqueles que sofrem as injustiças o fizessem, porque ainda não tiveram fé ou porque ainda não pagaram um propósito para alcançar uma benevolência de Deus. (SILVA, 2008, p.07).

Outro autor de destaque na cena underground é Flavio Rodrigues, do livro O rock na evangelização (2006), que desenvolve a ideia, a partir do famoso missionário norte-americano Francis Schaeffer, de como foi e ainda é difícil para os evangélicos em geral encarar o mundo-que-aí-está:

Temos de compreender que estamos enfrentando uma situação histórica que sofre rápidas transformações e, se vamos nos lançar à obra de falar acerca do Evangelho, precisamos conhecer qual a presente flutuação das formas de pensamento. A menos que assim façamos, os imutáveis princípios do Cristianismo cairão em ouvidos surdos. E se visamos a alcançar os intelectuais e os operários, dois grupos que se acham além do âmbito de nossas igrejas de classe média, então impõe-se a nós um minucioso esquadrinhamento do coração quanto a como podemos falar sobre o que é eterno em uma situação histórica em constante mudança. (apud RODRIGUES, 2006, p. 67).

Indo a fundo na reflexão, Rodrigues coloca o problema supracitado como produto da falta de reflexão da realidade cotidiana pelos cristãos adultos, não se esforçando nem para compreender as várias manifestações culturais, 
muito menos para entender minimamente o que os jovens, de fato, anseiam. $\mathrm{E}$ termina citando novamente Schaeffer:

De um modo paralelo, estamos sendo tão abusivamente injustos, até mesmo egoístas, em relação à nossa própria geração, como se os missionários, tivessem deliberadamente falado um só dialeto. A razão por que não podemos falar a nossos filhos, muito menos aos outros, é que jamais ponderamos quão diferentes das nossas são suas formas de pensamento. Muitos pais, ministros e educadores cristãos estão, na atualidade, tão fora de sintonia com os numerosos contingentes de filhos da própria Igreja e com a vasta maioria dos que não lhe pertencem, como se estivessem falando uma língua estrangeira. (apud RODRIGUES, 2006, p. 68).

É nesse fundo de dilemas, contradições e atitudes que os segmentos juvenis tem se posicionado no campo cristão e nos ambientes seculares. Não podemos esquecer que esses novos jovens cristãos são frutos de um cenário marcado pelo crescimento socioeconômico em alguns lugares e o aumento da pobreza em outros; pela ampliação do acesso à educação nas grandes cidades e a consequente explosão de "diplomados sem emprego" por outro; pelo incremento da oferta de bens e equipamentos culturais e a persistência da reprodução das desigualdades sociais com base no capital cultural; enfim, estamos diante de um cenário "pós-moderno" que assombra uma juventude que, sedenta de afirmação e protagonismo, não encontra com a mesma facilidade de outrora uma base firme e sólida para se ancorar. Nesse esteio, a religião, assim como a sociedade, as instituições e os sujeitos individuais em sua personalidade, são feitos e transformados em moldes cada vez mais complexos, híbridos e ambivalentes.

A juventude religiosa busca amparo espiritual, místico e sobrenatural para transformar a sua existência social, criar outros vínculos afetivos e estabelecer um compromisso com uma missão. E essa busca precisa de marcadores e mediadores espaciais para tornar o sagrado mais acessível, inteligível para o jovem. Como elementos materiais de marcação e de mediação do sagrado, há santuários, templos, capelas e, mais recentemente, casas, garagens, galpões semiabandonados, sítios, festas rave e shows de metal. São transformações religiosas impostas pela cultura ocidental 
secularizada (hiper-modernizada) que obrigam as Igrejas evangélicas e cristãs em geral a adotar uma postura crítica em relação à sua própria prática missiológica e relacional, e a rever alguns elementos que tradicionalmente balizaram sua formação institucional: hierarquia de funções, doutrina, dogma, regras morais e a tradicionalíssima conduta ascética que ressoa desde tempos weberianos $^{9}$.

Pela análise de algumas pesquisas quantitativas e qualitativas feitas por cientistas da religião e alguns teólogos, mesmo com a abertura maciça das igrejas evangélicas e alternativas para as influências seculares das culturas juvenis e de massa - ampliando e fortalecendo o mercado de bens religiosos católico e evangélico em todo o Brasil - elas vêm perdendo considerável influência no universo jovem e secular devido a alguns elementos endógenos julgados inadequados na atualidade. Listo aqui alguns desses possíveis pontos negativos que tem gerado, como mostro em Cardoso (2011), um progressivo afastamento de alguns segmentos jovens dos templos evangélicos: hierarquismo excessivo, burocratismo institucional, baixo personalismo da membresia, visão (neo)liberal da maior parte dos líderes, alienação excessiva dos fiéis leigos, intolerância religiosa e contra alguns segmentos sociais, falta de ação social eficaz e libertária.

E se não bastasse, ainda temos a atual explosão de denúncias de corrupção, enriquecimento descomedido, politicagem e outros crimes e desonestidades envolvendo líderes evangélicos proeminentes.

Diante de um cenário ambivalente, há que se pensar o porquê da mudança na mentalidade dos novos (e velhos) jovens cristãos e como as Igrejas católica e evangélica, diante de tanto denuncismo público e de falhas na administração interna de seus templos e organizações, poderá se reconectar com a juventude urbana e com as culturas não-hegemônicas de modo mais geral.

As transformações na intimidade religiosa, nos mapas de afeto dos jovens brasileiros têm despertado a atenção de cientistas, intelectuais, teólogos, denominações e outros atores sociais. Contudo, vemos uma carência

\footnotetext{
${ }^{9}$ Refiro-me ao pensamento de Max Weber que iniciou toda uma onda de análises sobre o ascetismo protestante/pietista/puritano a partir do seu livro Ética protestante e o espírito do capitalismo (2002).
} 
de estudos empíricos para corroborar as afirmativas teóricas a respeito da descentralização das instituições religiosas dominantes e da pulverização de práticas religiosas místico-esotéricas/regionais/orientais - em suma, que não se atém ao modo tradicional ocidental católico ou protestante de experimentar o sagrado e se relacionar com uma instituição religiosa.

Há uma profusão de novos segmentos jovens religiosos que optaram por adotar uma "cultura religiosa errante", ou seja, uma religiosidade porosa, performática, festiva, efêmera, sem marcos doutrinários estanques, carente de um elemento teológico vertebrador, que só tem como prática duradoura a contínua dessubstancialização e desterritorialização do espaço sagrado e da vivência do indivíduo com o mundo espiritual. Nesse conturbado e criativo cenário, há de se pensar se os evangélicos não te experimentado um período de decrescimento da conversão de jovens e de adesão por parte deles à rotina confessional. Geograficamente, está em questão aqui a perda progressiva da importância do templo, do espaço físico sacralizado como mediador territorial da expressão do sagrado, da comunitarização de fiéis.

Mas diante do crescimento abrupto de templos evangélicos, comunidades carismáticas católicas, círculos espíritas e saberes e instituições místicas e neo-esotéricas, cabe então perguntar: Por que os jovens estão cada vez mais avessos às instituições e optando por um estilo de vida eremita ou, na melhor das hipóteses, por uma vivência mens formalizada com a espiritualidade e com os grupos de pares (NOVAES, 2006; AMARAL, 2000)? Que atmosfera social, cultural e "espiritual" tem dirigido o habitus dos jovens a ponto de hoje podermos falar com convicção que o Ocidente vive um período pós-cristão e "pós-santuarial"10?

A hipótese de que há uma parcela considerável da juventude cristã que está aderindo ao vitalismo - isto é, um modo de conceber e viver a vida desapegado de tudo o que, supostamente, corrói, impede ou destroça as

\footnotetext{
${ }^{10}$ Santuarial: relativo a todo espaço que se qualifica como santuário, templo religioso. Como essa expressão, não se quer dizer que vivemos a era do fim dos templos, como os cristãos undergrounds bravejam com prazer - veja <http://fimdostemplos.blogspot.com.br/>, blog do pastor Paulo Garcia, do Milícia Missões Urbanas (ES) -, mas que a relação das pessoas e grupos com o sagrado, o mysterium tremendum, o numinoso (OTTO, 1992), modificou-se consideravelmente no último século. Exemplos de que os santuários continuam vivos e ativos são dados por Rosendahl (2008a, 2008b, 1999), Santos (2010) e Oliveira (2004).
} 
capacidades criadoras e a liberdade individual(ista) do ser humano -, é procedente e preocupante. A pessoa humana é vista, nesse ponto, como uma entidade dotada de um élan vital, uma essência que só se realiza por completo se não houver a presença de instituições, rituais, comunidade ou quaisquer outros mecanismos repressivos da ordem social.

Como corrente filosófica e teleológica, o vitalismo é a zeitgeist mais influente hoje no mundo ocidental capitalista. Ele reina como pensamento pseudo-emacipador desde o século XIX, sendo o filósofo alemão Nietzsche o seu principal divulgador (suas ideias de super-homem, vontade de poder, morte de Deus, do perspectivismo e da vida dionisíaca são marcas do pensamento vitalista). O vitalismo segue o seu percurso anti-ritualista no Ocidente através do pós-estruturalismo francês, do pós-modernismo e das teologias pósmodernas e neoliberais, que são nada mais nada menos que reflexos místicointelectuais de um período onto-gnosiológico da sociedade de massa e consumo que adentra o século XXI.

Um novo período de crise acumulativa do capital requer das estruturas econômicas e políticas um novo método de aquisições, um novo ensejo espiritual que leve a novas fontes de recursos, receita e prestígio. Tal ânsia é para que as engrenagens societárias não se enferrujem e se desfaçam. Uma situação aparencial como essa é conformadora de paisagens que, sob um viés crítico, permitem entender como o capitalismo está numa fase "excremental" (a escola wallersteiniana fala em estado terminal!), restando a ele somente investir em novas situações vicárias simuladoras da geografia do mundo (HARVEY, 1992). E investe-se também na diferenciação e produtividade espaciais (SANTOS, 1999) que garantirá o lucro ampliado.

E o Brasil urbano e religioso não escapa desse fenômeno de ideais e traços anti-institucionais e anti-hierárquicos (mas que não chegam a se configurar em anarquismo ou outra coisa do tipo). O vitalismo encara os fenômenos, coisas, enfim, o cotidiano da sociedade e da natureza numa perspectiva radicalmente diferente da posição ritual comum às religiões tradicionais. $O$ entanto, foi a tal ritualidade das religiões que permitiu o contato com outros mundos, sendo o convercionismo, marca fundante do cristianismo, 
uma questão de diálogo intercultural ou de pura e simples imposição política, como ocorreu no período colonial-imperial.

Agora, todo o campo religioso brasileiro se vê diante de uma alterglobalização capitalista submetida às novas tecnologias, à ciência "laica", às mídias e ao voluntarismo burguês, num movimento que ousa expurgar tudo o que é velho, místico-mágico, arcano e hierárquico. Em outras palavras, tudo aquilo que emperra o progresso e o desenvolvimento socioeconômico. As religiões precisam se adaptar a esse admirável mundo de inovações e imposições. Os evangélicos já estão nele faz algum tempo. Já os católicos, caminham pelas beiradas, porém sem fazer muito alarde. Enquanto isso, a geração emergente e suas múltiplas faces caminham a passos largos em direção à pós-modernidade e a um novo modelo de gestão comunitária e do sagrado que não pretende fugir do mundo, pelo contrário, quer fazer parte dele.

Mas não seria esse modelo uma mera reatualização do ascetismo intramundano protestante europeu da qual nos falara Weber?

\section{Underground cristão: o flerte com as culturas urbanas secularizadas}

Underground cristão, termo consolidado pelos nativos e usado também por alguns jovens evangélicos, é um termo controverso e suscita as mais diferentes dúvidas e reações. A tentativa aqui é de resumir as reflexões feitas por mim nos últimos anos, cuja pesquisa resultou em um "outro" plano de compreensão sobre o arranjo do movimento pós1980 (no total, cinco momentos histórico-espaciais), e na invenção (ou melhoria) de duas metodologias de análise: a etnogeografia multiterritorial e a etnogeografia da memória (CARDOSO, 2011).

Como fruto de um momento histórico na qual protagonismos juvenis insurgi(r)am em todos os setores da sociedade brasileira, o underground cristão consiste na versão religiosa do movimento musical mundial dos anos 1980, que engendrou gêneros musicais como o heavy metal, death metal, gótico, hip-hop, e revisitou outros "antigos" como o punk e o rock progressivo. Mas não só de musicalidades vive o underground cristão: teatro, percussão, 
pintura e outras artes estão incluídos na lista de expressões religiosas performáticas.

Tal como em todas as culturas jovens hedonistas da sociedade pósmoderna massiva, os undergrounds apresentam estratégias espaciais que variam mediante as especificidades de cada cidade e localidades de lazer, interação e entretenimento. As similitudes começam a transbordar quando se vê esses jovens religiosos traçando os mesmos itinerários geográficos dos grupamentos jovens seculares, incluindo a frequência aos points alternativos da cidade, num deslocamento que apela para o estético, para o espontâneo, para a presentificação de um momento que representa a fuga de todas as obrigações cotidianas, exceto uma: aonde quer que estejam, precisam portarse como cristãos autênticos, como mensageiros do Reino. E é aqui que a ideia de missionário urbano fica mais tangível e aberta a qualquer desdobramento performático (pirotecnia, música, teatro, pregação). Aliado ao momento de descontração, quase sempre o "bate-papo" termina com assunto polêmico, seja um assunto que se refere a algum membro da comunidade que não está "bem inserido", ou às notícias sobre o meio evangélico quase sempre em tom de crítica e escárnio.

Tal como nas experiências jovens na cidade, o point é o centro de referência, o lugar onde as distintas trajetórias jovens se encontram e interagem. Oriundos de localidades diversas, os undergrounds adoram frequentar os mesmos bares, ruas, centros culturais e casas de evento das juventudes seculares para mostrar a eles que fazem parte de uma mesma "tribo", todos estão juntos e misturados, como adoram falar alguns pastores emergentes.

O estilo visual $e$ as ações performáticas são o que define a territorialidade de cada cluster cultural, e os cristãos undergrounds e emergentes sabem muito bem os graus de abertura que grupo dá para aceitar visitas de outsiders. Esse grau muda em virtude do lugar, dos outros grupos que estão em volta e das atrações do dia, mas o principal elemento de acesso a um grupo de estilo é, realmente, o estilo. Mas isso é um assunto longo e que não cabe neste texto. Voltemos então à composição do underground cristão... 
A pergunta que todos fazem é: onde, quando e como começou o movimento underground cristão? Na verdade, as divergências ideológicas já começam quando o objetivo é definir os estilos, as cosmologias, a doutrina bíblica, em suma, o repertório artístico-cultural e teológico que embasa as comunidades eclesiais e agências missionárias undergrounds. Ninguém chega a um consenso... Entretanto, todos os militantes são peremptórios em afirmar que a luta não é pela institucionalização, e sim pelo avanço da evangelização aos segmentos jovens urbanos excluídos dos proselitismos evangélico e católico. Percebe-se aqui que o vitalismo "a la Nietzsche" é quem dá as ordens no movimento, mesmo sendo o protestantismo o estilo de vida que mais influencia as ideias, crenças e práticas das lideranças e dos fiéis undergrounds.

Pelo fato do movimento aderir à onda filosófica vitalista, então as águas que movem o moinho do underground cristão e de outros ramos nãoconvencionais partem de situações nas quais as fronteiras são extremamente porosas, simbólicas. Com isso, e baseado na minha experiência de campo e como ex-integrante do movimento, quero dizer que os fiéis e líderes undergrounds transitam fortemente por entre comunidades alternativas e evangélicas, firmam parcerias seja com evangélicos ou pessoas seculares, e lutam por visibilidade tanto no underground quanto no mainstream.

Abaixo, está uma tentativa de esquematização da formação do movimento no Brasil (CARDOSO, 2011, p. 78-81) a partir de ciclos espaçotemporais (que chamei de ondas).

"Protótipo" de onda: 1970-1985

Protagonistas: missionária Bugra (SC), Comunidade S8 (RJ), Cristo Salva (SP), Atletas de Cristo (SP), Volantes de Cristo (Brasil); bandas Rebanhão (RJ), Êxodos (RJ);

Influências estéticas e musicais: contracultura juvenil, rock psicodélico, blues-rock, baião.

Público-alvo: hippies, rockeiros, dependentes químicos, alcoólatras. 
Lógica espacial: lugares de encontro dos grupos, principalmente praças; reuniões de comunhão e de ritualização em igrejas evangélicas de perfil "aberto"; pouca interação espacial entre os missionários vanguardistas.

Signos territoriais: praça, templo evangélico.

\section{Primeira onda: $1985-1989$}

Protagonistas: líderes Claudio Tibérius (SP), Luciano Manga (SP), Fábio Carvalho (Paraná e depois Minas Gerais), Comunidade S8 (RJ); bandas Katsbarnea (SP), Rebanhão (RJ).

Influências estéticas e musicais: rock neoprogressivo, hard rock, soft rock, heavy metal clássico, thrash metal.

Público-alvo: punks, headbangers, darks, góticos, carecas.

Lógica espacial: evangelismo de rua individual, reuniões esporádicas e maior quantidade de jovens envolvidos na "luta". Os militantes continuam dispersos

Signos territoriais: rua.

Segunda onda: 1990-1999

Protagonistas: I Congresso Brasileiro Headbanger Cristão (SP), Christian Metal Force; pastores Claudio Tibérius, Sandro Baggio, Fábio Carvalho, Luciano Manga, Refúgio do rock (SP), Metanóia (RJ), Caverna de Adulão (MG); bandas Necromanicider (RJ), Antidemon (SP), Oficina G-3 (SP), Resgate (SP), Fruto Sagrado (SP), Berith (SP), Stauros (SC), The Joke (MG), Catedral (RJ), Kadoshi (SP).

Influências estéticas e musicais: thrash metal, heavy metal, death metal, gótico, hard rock, rock progressivo, pop rock.

Público-alvo: punks, headbangers, hardcores, góticos, carecas, satanistas.

Lógica espacial: aluguel de galpões ou aproveitamento dos espaços anexos das igrejas para promover os cultos; intensificação dos evangelismos de rua com microgrupos; primeiras bandas de metal cristão tocando em shows seculares.

Signos territoriais: show, rua, praça. 


\section{Terceira onda: 2000-2007(?)}

Protagonistas: Bola de Neve Church (SP), Tribal Generation (MG), Zadoque (SP), Ajuntamento das Tribos (RJ), Comunidade Gólgota (PR), Caverna de Adulão (MG), Projeto 242 (SP), Galpão Cultural S8 (RJ); pastores Jesus (RJ), Enok (RJ), Fábio Carvalho (MG), Batista (SP); bandas Seventh Angels (PR), Antidemon (SP), Skymetal (MG), Stauros (SC), Desertor (PR), Blasterror (RJ), Trino (ES), DJ Alpiste (SP), Apocalipse XVI (SP).

Influências estéticas e musicais: metal progressivo, death metal, glam-rock, punk, hip-hop (rap, graffiti), clubber.

Público-alvo: headbangers, punks, carecas, hippies, clubbers, hardcoreanos, satanistas, vampiristas, hip hoppers, reggaeiros, grunges, surfistas.

Lógica espacial: difusão do movimento nas outras regiões do Brasil (notadamente Nordeste e Norte), com a emergência de outras expressões estéticas dentro da visão e missão do underground cristão; criação de agências missionárias de formação de líderes e de plantação de igrejas alternativas; maior diálogo com os evangélicos; eventos de integração local e regional; uso esporádico do ciberespaço e das mídias alternativas.

Signos territoriais: point, show, comunidade local.

Quarta onda: 2007-?

Protagonistas: Ajuntamento das Tribos (RJ), Avalanche (ES), Manifesto Missões Urbanas (MG), Vineyard/Sexxx Church (SP), ZOE (TO), Sabaoth (AC), Verbalizando (RJ), Underfaith (SP); bandas Oficina G-3 (SP), Zebulom (AC), Arnion (GO), Krig (MG), Sentido Oposto (RJ), Pingo d'água (RJ), Metanóia Worship (RJ), Ruah Jah (RJ), Doxologia (RJ), Vox (ES), Trino (ES), Desertor (PR), Sangue Inocente (SP), DJ Alpiste (SP), Apocalipse XVI (SP), Mano Reco (SP), Ministério Éfeso (SP); líderes Claudio Tibérius (SP), Olgálvaro Junior (MG), Diniz (ES), Evandro Sudré (SP), Marcos Ribeiro (RJ).

Influências estéticas e musicais: emo, metalcore, metal progressivo, death metal, hardcore, hip hop (rap, graffiti, poesia, break), "MPB".

Público-alvo: emos, headbangers, hardcoreanos, skatistas, hip hoppers, reggaeiros, universitários, e "outras pessoas". 
Lógica espacial: eventos de integração local e regional; empoderamento das agências missionárias; intercâmbio pontual com missionários undergrounds da América Latina; turnês de bandas "famosas" (Saint Spirit, Antidemon, Krig); refluxo do proselitismo de "rua" e mais agenciamentos no interior dos grupos (reuniões de confraternização, encontros rituais, festivais anuais); uso intenso do ciberespaço e das novas tecnologias; fechamento identitário de alguns grupos, abertura "estratégica" de outros conforme o contexto e recursos financeiros.

Signos territoriais: comunidade local, show, encontros "regionais".

Diante desse esquema cíclico, e entendendo o estilo e a posição de cada sujeito coletivo e pessoal ali listado, já podemos elaborar uma definição, embora variável e porosa, do que seja o underground cristão. Primeiramente, trata-se de um novo movimento religioso (GUERRIERO, 2006), de culturas religiosas com traços e marcos próprios das juventudes midiáticas urbanas.

Configurados como igrejas, organizações missionárias, promotores de festivais etc., o underground cristão ainda é uma incógnita, um "movimento sem rumo", porém, o protagonismo desses jovens é revelador de uma condição pós-moderna na qual as instituições cristãs hegemônicas passam a ter de rever permanentemente seus preceitos, dogmas, liturgia e meios de acessar outras culturas e segmentos sociais. As agencialidades que con-formam 0 underground cristão encontram-se inscritas em um horizonte de práticas culturais altamente ritualizadas, mas sem perder de vista o vitalismo que os fazem crer que as instituições religiosas são um modelo obsoleto, falido. Deste modo, lugares e territórios religiosos são cuidadosamente produzidos para atender a essa demanda por um cenário sociocultural que não mais atura as pressões advindas de estruturas religiosas monolíticas. Ao passo que os lugares e territórios são esteticamente criados e sacralizados em rituais e encontros espirituais, o campo religioso começa a se fragmentar em estilhaços de identidades e adentra numa crise de representação que chega ao cúmulo de se questionar, no próprio interstício da comunidade eclesial, as bases da crença à qual se adere. $\mathrm{O}$ lugar, o território e a consequente paisagem religiosa 
erigida pela representação tornam-se um patrimônio da qual todos os fiéis da comunidade precisam se apropriar e potencializar.

Tomando o Crash Church - nova roupagem da antiga e badalada Comunidade Zadoque - como exemplo, Pinto analisa o veio potencialístico presente nas práticas culturais da cena e relativiza a postura funcionalista de algumas explicações que intentam colocar o jovem religioso como agente "carente", "em busca de mera solução existencial para os problemas cotidianos":

Contrariamente à generalização e à ligação direta entre pobreza e determinados movimentos identitários presente nas explicações funcionalistas, acredito que, no caso dos jovens da Crash Church e do underground evangélico, o papel central da religião em suas vidas é o de conferir a eles agencialidade. Vivenciar a crença não se limita a um sentimento de libertação ou a uma mudança de comportamento, mas implica em entrar em um estado de potencialidade, de um vir-a-ser em uma banda famosa, em um estúdio de tatuagem reconhecido, em uma galeria de artes gráficas, em um livro de poemas góticos. Assim, para estes jovens, se envolver no campo de práticas sociais do rock evangélico não se esgota em uma opção estética; significa se situarem enquanto agentes sociais atuantes. Eles tomam os elementos constitutivos dos universos simbólicos do rock e da religião evangélica como forma de construir e de reafirmar os valores e todo o conjunto de ideias sobre o modo de vida em que acreditam, moldando a partir disso seu próprio cotidiano (PINTO, 2009, p.179-180).

Os novos movimentos religiosos não são iguais à atual onda de mobilizações religiosas que brotou e adentrou em todas as fissuras do campo religioso brasileiro. Esta última tem dinâmicas de localização, territorialização e regulação diferenciadas: são ações mais fragmentadas e desregulamentadas, sem nenhum núcleo que defina as regras ou advogue a favor de um ou outro grupo. Enquanto os novos movimentos tem um perfil (mesmo que sorrateiro) de unidade na diversidade, as novas mobilizações são um exemplo da mais banal ação e retórica anárquicas, na qual a política da diversidade já se encontra em estado caótico, sem nenhum direcionamento ou possibilidade de compartilhamento das agências. Nenhum órgão ou política de cooperação consegue reuni-los em nome de uma cultura, crença, líder, entidade ou projeto comum. O máximo que se consegue em tais fenômenos é a criação de 
unidades de mobilização, dentro de uma concepção derradeira do que é sagrado e daquilo que se faz chegar a ele, em outras palavras, uma conduta de vida não-religiosa, ou "desrreligiosizada" se o caso é desconstruir a visão tradicional que os jovens tem do sagrado, do ofício sacerdotal e da hierarquia própria de uma comunidade baseada na coesão e integração social.

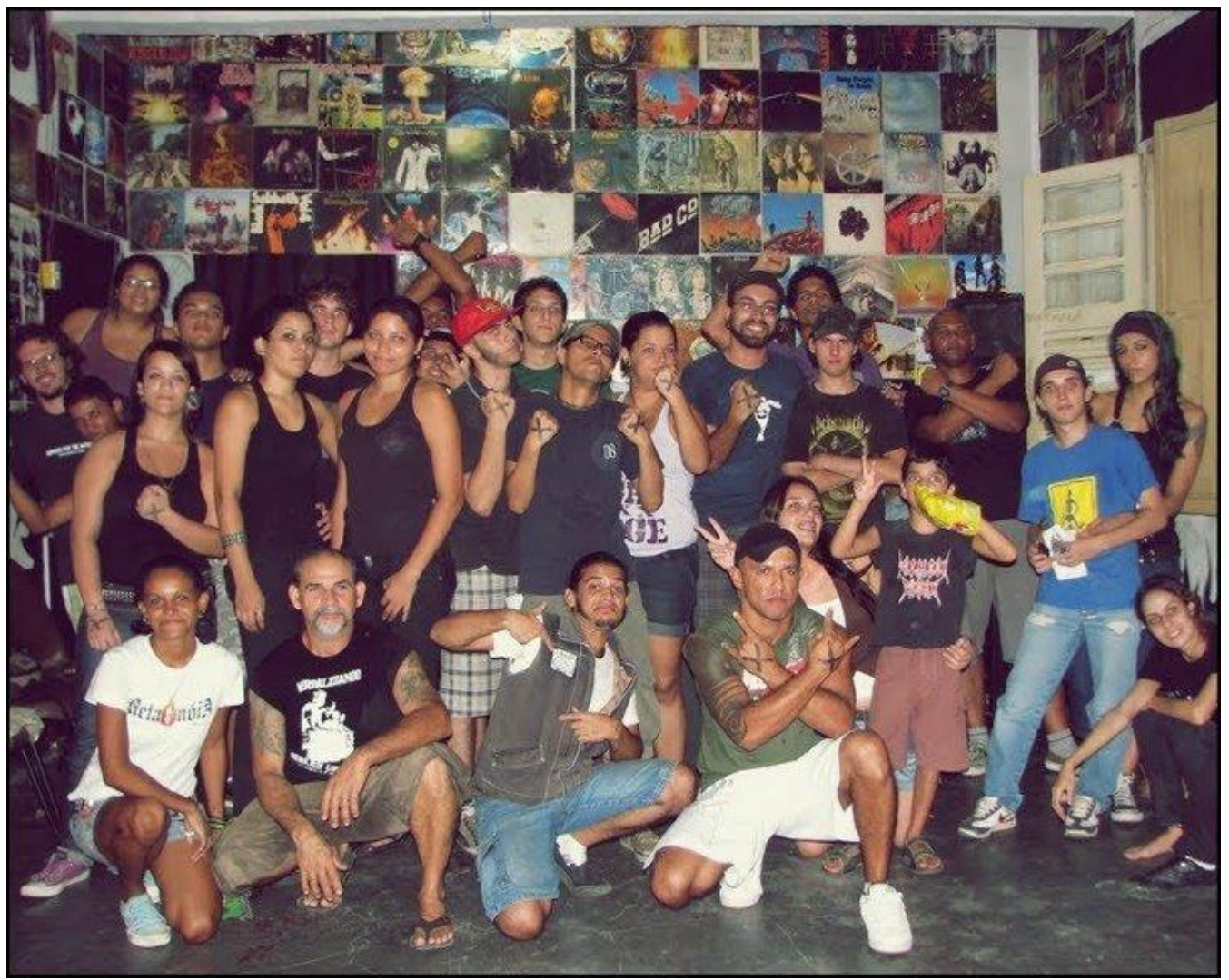

Imagem 1: O Metanóia (RJ) e a sua tentativa de conciliar os diferentes jovens dentro de um mesmo território sustentado pelos gêneros rock e heavy metal, estilos que simbolizam a liberação religiosa e a subversão juvenil. Fonte: arquivo pessoal. Agradeço a Fabiana Rufino pela cessão da foto (2012).

Geralmente, os jovens antes congregados em instituições protestantes, católicas ou de outras religiosidades passam por um turvo e turbulento processo de "desrreligiosização", onde os ganhos e perdas psicológicas são inerentes. No mais das vezes, impera um (grave) senso de que o que antes se fazia foi "perda de tempo", ações e ritualismos fúteis, desnecessários. É preciso recuperar o tempo perdido... O underground cristão seria uma espécie de solução cultural para uma defasagem que está no plano da religião, da 
existência concreta desses sujeitos em redes sociais e espaços de vivência que extrapolam as fronteiras do poder religioso.

Mas para desenvolver melhor o debate, precisamos entender o que é uma unidade de mobilização - e os seus correlatos sociológicos: grupodispositivo e irmandade multifacética - e a produção de sensações religiosas contemporâneas que partem da concepção do sagrado como algo fluido, incomensurável - no linguajar deleuze-guattariano, em permanente estado de des-re-territorialização.

Tais unidades de mobilização configuram eventos, grupamentos, ritos e rituais simultaneamente heterogêneos e particularistas, com teor aberto, "ecumênico" e ao mesmo tempo fechado e confrarial. Não há melhor exemplo do que o próprio underground cristão: não há unidade neste movimento, por isso, opto estudiosos e leitores tem optado por caracterizá-lo como uma cosmovisão abrangente que trabalha sob o manto da invisibilidade resignada: gostariam de ser visíveis, mas por não conseguirem (não possuem meios ou carisma suficientes para chegar a esse estado), optam por agir de modo sorrateiro e performático nas fissuras deixadas pelos evangélicos para, através justamente da invisibilidade que os evangélicos produziram sobre eles, poderem intervir de forma "livre" e criativa. Eles almejam três coisas: 1) gozar de uma suposta liberdade em relação a "ideologia economicista" (teologia da prosperidade neopentecostal) e ao "corporativismo despersonalizado" (protestantes históricos) dignos das instituições hegemônicas; 2) sentir-se separado do "grande sistema", e isso compreende não só estar livre da religião institucionalizada, mas também do cotidiano burocrático e culturalmente empobrecido e dominado pelos meios de comunicação de massa, um cotidiano que, na leitura teológica deles, “jaz dominado por Satanás”. Evoca-se aqui o apocalipse como visão premonitória do fim dos temp(I)os...

Para uma visão geral da modernidade religiosa, não se deve esquecer os dois pilares básicos de uma religiosidade: crença e fé. A crença, por uma série de eventos e processos na vida social, encontra-se inerentemente ancorada num sistema, e para tal, obrigatoriamente carece de ser justificável, 
procurando sempre sua legitimidade frente a outros sistemas religiosos e de crença (OLIVEIRA, 2004).

Já a fé religiosa, esta sim não precisa de nada que a dê suporte, pois a sua manifestação é diretamente ligada à motivação da pessoa. Mas na contemporaneidade, visto que os fenômenos sociais e culturais tendem a adquirir um caráter de massa (desde que estejam ajustados à lógica do mercado), a aparição máxima da fé tem se dado nos coletivos religiosos, que Ihe dá sentido, volume e, não raro, institucionalidade - sobre isso, basta notar o campo neopentecostal e as suas práticas de "institucionalização mística da fé".

Pode-se afirmar, diante de todo o esquema conceitual da modernidade religiosa, das novas frentes de mobilização e pertença religiosa e da concepção fluida e multiterritorializada do sagrado, que o fenômeno da dupla, tripla, chegando às vezes até a uma "poli-denominacionalidade", já é um acontecimento em algumas cidades brasileiras. Com certeza são os jovens pós-adolescência o público mais propenso a tal prática multifacética, embora os novaeristas e outros segmentos "adultos" compartilhem da mesma visão de que só no trânsito e na desinstitucionalização da religião é que se conquista a autêntica religiosidade e experiência do sagrado.

A voz é um dos elementos de destaque nos gêneros de heavy metal, e não é para menos: ela materializa o gênero musical e torna objetivo, "palpável" os sentimentos do artista no instante da gravação. Seguindo essa perspectiva, a voz faz a música ganhar corpo, ratifica a corporalidade da pessoa que a cantou. Sua existência é datada e situada, é verdade, mas é digna de ser apropriada pelos fãs no cotidiano e nos eventos de lazer e entretenimento, ao qual reproduzem e reatualizam os sentimentos impressos na gravação. Vozes líricas, estridentes, guturais, surreais e embravecidas constam nesses estilos, cada um colaborando para tornar seu respectivo gênero musical um fenômeno ao mesmo tempo particular e instável. E digo "instável" porque os gêneros de metal estão cada vez mais híbridos, sem fronteiras definidas, como é o caso do gótico, que tem acrescentado em seu repertório outros vocais, deixando o lírico cada vez mais dependente dos gritos guturais, surreais e aguerridos.

A condição de escuta do heavy metal coloca instantaneamente o vocal 
como um dos principais indicadores do sucesso de uma banda. O vocal é que baliza os demais instrumentos e recria a atmosfera que se quer dar à música. Assim, enquanto no heavy metal clássico o vocal lírico nos leva a um clima épico-medieval, onde paixões, encontros e incertezas dão a tônica dos acontecimentos, no subgênero death metal, o vocal gutural deixa mais que evidente o tom catastrofista e aflitivo das letras, um retrato artístico fidedigno do modo de pensar dos músicos e do cenário que se pretende retratar (guerra, violência urbana, tortura, catástrofe natural, perseguição religiosa).

Mas não é de hoje que tamanha exigência é feita aos artistas. Gumbrecht relata a história de Edith Piaf, exímia cantora francesa que teve seu auge nos anos 1940-50, ao gravar discos que literalmente "exibiam" sua voz aos ouvintes, ou seja, sua voz encarnava todo o sentimento corpóreo daquele instante, tornando sua voz um objeto palpável, "mais 'real' do que a imagem de um corpo jamais poderia ser" (GUMBRECHT, 1998, p. 134).

É difícil afirmar com exatidão essas perguntas, até porque, no decorrer da interação com o pessoal underground e nos diversos zines e blogs de fiéis que li, constatei que são poucos os que se interessam (e realmente lutam) para chegar a uma conclusão sobre a história e os territórios do movimento. Terá sido a Comunidade S8 (RJ) a primeira Igreja alternativa? E a missionária Bugra, terá sido ela a primeira evangelizadora de hippies? E o que falar de Claudio Tibérius, primeiro headbanger cristão a enfrentar carecas, punks e metalheads nas ruas de São Paulo dos anos 80? O Avalanche Missões Urbanas (ES) é a primeira agência missionária underground? Essas e outras perguntas devem ser respondidas pouco a pouco, preferencialmente com a participação de todos aqueles que defendem com "unhas e dentes" a cena.

Para continuar o texto em tom prognóstico, colocarei mais dúvidas quanto a uma situação que vem incomodando bastante as lideranças emergentes, undergrounds e evangélicas brasileiras. Trata-se dos desafios futuros a serem percorridos pelos jovens cristãos e da luta das instituições eclesiásticas pela manutenção da sua hegemonia. Numa era em que a secularização e a massificação dos bens culturais abrem novos horizontes de disputa simbólica, mediação cultural e protagonismo estético, conformando 
novas sociações juvenis cuja finalidade é tão somente, promover o "estar junto", o "curtir com a galera", o "fazer nós mesmos", o "lutar pelos nossos ideais", o "ter uma atitude", entre outros.

\section{Desafios: "O que Virá?"}

No Ajuntamento das Tribos de $2010^{11}$, no agradável sítio Soreba, em Itaboraí (RJ) - pertencente a uma Igreja Batista local -, o slogan do evento foi: "O que virá?". Tal frase resume o dilema religioso presente entre os jovens da cena e que incomoda os teólogos undergrounds, evangélicos e os cientistas. É um dilema que envolve todas as comunidades eclesiásticas, ONG's e grupos artísticos cristãos: que cultura religiosa, ou melhor, que igreja e pessoas cristãs queremos para o futuro?

Dando continuidade às reflexões que houve no encontro anterior (2009) na Comunidade S8 (São Gonçalo, RJ), o debate foi ainda mais (in)tenso. Dos grupos de reflexão formados pelas lideranças do underground aos shows de bandas $^{12}$, tudo foi muito acalorado, sem tempo para ritos desnecessários ou outros melodramas. O negócio era ter uma visão crítica da realidade do underground cristão e o papel do movimento junto aos evangélicos para dirimir os problemas estruturais que acometeram quase todos os setores evangélicos (corrupção, ideologia da prosperidade, fundamentalismo bíblico, sectarismo) e seguir em frente com a principal incumbência de um cristão: divulgar os princípios bíblicos e "ajudar" o Outro a se converter a Cristo.

Antes e depois do evento, as lideranças (principalmente da lgreja Ajuntamento das Tribos), traçaram o seguinte diagnóstico de falhas hoje verificadas em todo o movimento (CARDOSO, 2011, p.77) ${ }^{13}$ :

\footnotetext{
11 <http://www.youtube.com/watch?v=8haGR08gNoM\&feature=related> Acessado em: 10 out. 2010.

12 Basta ver os vídeos postados no Youtube, por exemplo: <http://www.youtube.com/watch?v=9ZjG3akE3l> (banda de louvor da lgreja Ajuntamento das Tribos) e $<$ http://www.youtube.com/watch? $\mathrm{v}=\mathrm{BfbOk2Qunfc}>$ (conversa com os principais mentores da cena, inclusive Geraldo Silva e Claudio Tibérius) - Acessados em: 10 out. 2010.

${ }^{13}$ Também disponível em: <http://www.ajuntamentodastribos.com.br/ajuntamento2010/cnuc.html> Acessado em: 01 set. 2010.
} 
a) Isolamento de alguns ministérios - trabalhar sozinho, em parceria, sem respaldo ou qualquer tipo de cobertura ou em unidade, minaram, em muitos aspectos, o avanço de muitos irmãos;

b) Descontinuidade - imaginar-se como ministério único, inovador, desvinculado de toda uma história que reconheça o esforço de movimentos evangélicos antigos, ou mesmo a conversão junto a igreja onde se deu os primeiros passos no evangelho é uma porta para a arrogância e o distanciamento. Muitos ministérios não se reconheciam como parte da mesma história cristã, mas uma ruptura, algo que deveria ter sido pensado e a igreja nunca fez;

c) Crítica cega contra a instituição - a crítica leviana à instituição, indiscriminadamente, gerou ministérios feridos com muitas igrejas e incapazes de reconhecer os esforços sinceros de muitas delas, através inclusive de suas lideranças, para estabelecer uma instituição saudável e capaz de fazer a diferença. Decretar a "falência" da Igreja, muitas vezes, acabou por prejudicar a aproximação e a possibilidade de uma caminhada comum;

d) Líderes com pouca trajetória e estrutura - a formação de um novo ministério, muitas vezes só atendeu ao capricho de alguns líderes (às vezes muito jovens, mas as vezes nem tão jovens assim), que insatisfeitos com suas congregações ou comunidades, persuadiram muitas outras "ovelhas", unidas pela identidade, a formar um outro projeto de missões urbanas.

Como superá-las? De acordo com alguns líderes que participaram do encontro, a solução é estreitar os laços com os evangélicos; já outros apontaram que há o perigo de ceder demais e perder a identidade e, com isso, todos os ganhos que o movimento com a crítica ao engessamento das igrejas; a saída do jovem de dentro do muro do templo; a adesão de todas as culturas marginalizadas; o uso de musicalidades alternativas; uma fé pautada mais na espiritualidade individual do que no gozo coletivo, etc. 
Em todas essas situações, o que está em jogo é a espacialidade, o rumo que o movimento tomará nos próximos anos; os meios de modificação dos espaços, lugares e paisagens religiosas em cadinhos de sacralidade extrema, onde o jovem possa, pura e simplesmente, prestar culto a Deus, "praticar o bem entre os Irmãos", aumentar a rede de amigos e desenvolver seus "dons" artísticos (quase sempre ligado à música ou teatro) e espirituais (quase sempre a glossolalia).

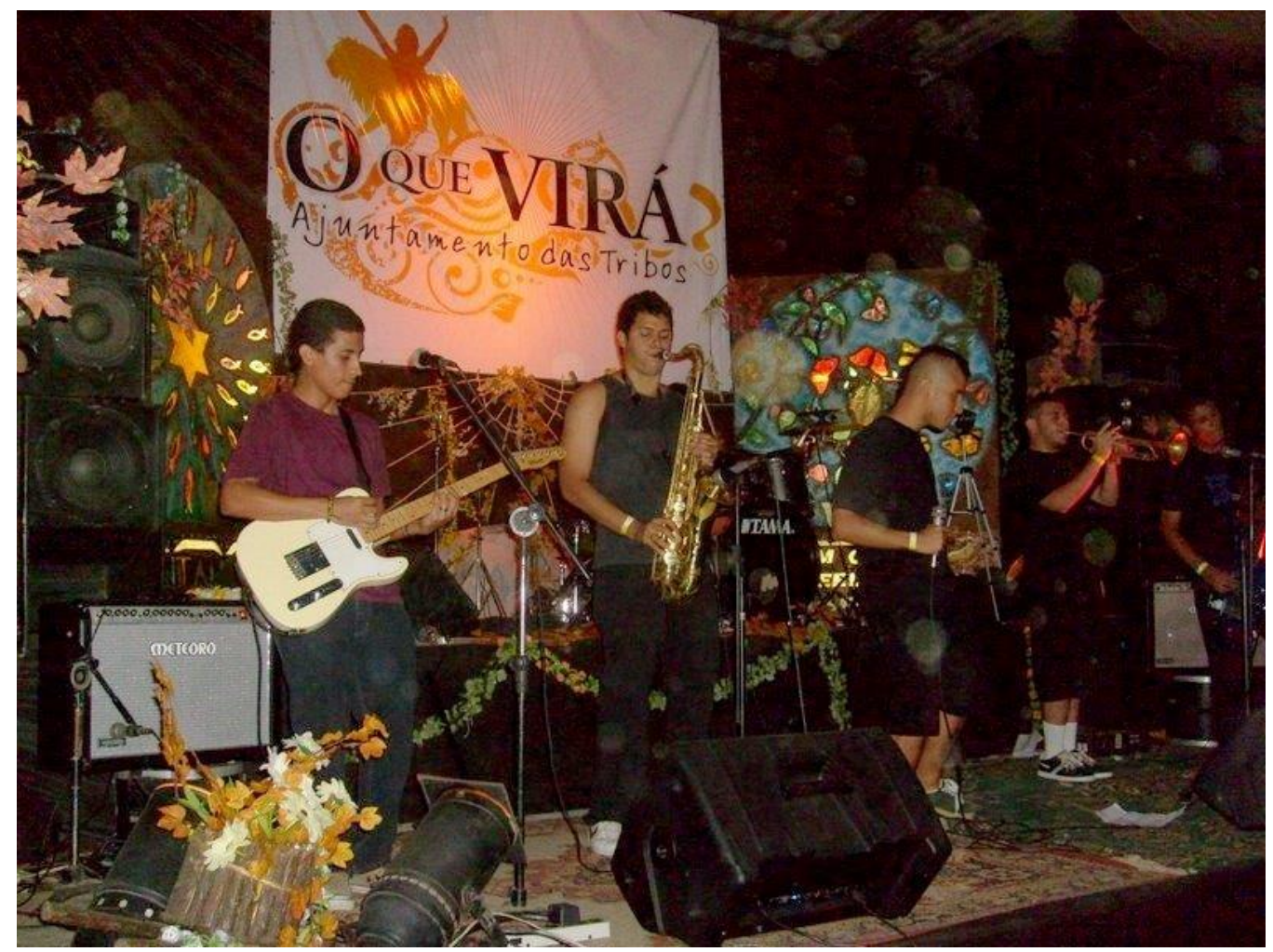

Imagem 2: Show de bandas no Ajuntamento das Tribos 2009. Reparem ao fundo a arte do evento e a frase: "O que Virá?". Fonte: Arquivo pessoal.

O fato é que, sendo um aglomerado de jovens contestadores dos usos e abusos do denominacionalismo evangélico, estão inseridos em um contexto cultural do qual é difícil sair: o da cultura comercial pós-moderna (mesmo que a ideologia deles não aceite tal ligação). Por outro lado, são adeptos de uma cosmovisão que segue os rastros tanto do cristianismo primitivo - da epístola aos Coríntios até a carta aos Hebreus, que criou todo o movimento neotestamentário - quanto da contracultura do século XX. Neste último caso, ler On the Road, do exímio autor e místico Jack Kerouac, escutar as bandas 
dos anos 80 , ler mangá e mostrar que tem atitude, é o perfil já clássico do jovem contemporâneo que busca na vida cultural juvenil do século XX.

Contudo, para borrar ainda mais as já porosas fronteiras simbólicas do movimento, temos hoje: emos, funkeiros, rappers, capoeiristas, motociclistas, "bicho-grilo" e mais um tanto de segmentos estéticos em disputa simbólica pelo controle "da interpretação infalível", da "verdade eterna". Eis o underground cristão.

A transgressão estética e o protesto político são as marcas do movimento, o que conflui para a produção de paisagens e territórios religiosos altamente estetizados, subversivos e... protestantes (doce ironia semântica!).

São jovens que ignoram em alguma medida a herança cultural cristã ocidental e buscam outras filosofias, teologias e conceitos que tratem da afirmação do primado da Cruz sem a necessidade de obnubilar o que "há de bom" de afirmação identitária e protagonismo religioso nos espaços, redes e circuitos que ainda oferecem resistência à divulgação do Evangelho. Caracterizam-se por travarem uma luta simbólica nos espaços públicos e nos recônditos das comunidades evangélicas, buscando meios para que se reconheça a sua estética particular e o compromisso espiritual que possuem tanto com a "Igreja" quanto com os jovens seculares discriminados. No caso aqui o descrito, tal carnaval é levado a cabo nos cultos conduzidos por jovens pastores tatuados e celebrados ao som de rock, heavy metal ou hip hop; nos percursos missionários pelos becos cinzentos e em shows típicos da periferia; além do intenso debate provocado por eles nas mídias sociais, em congressos próprios e nos encontros com outros crentes.

A guerra discursiva no meio evangélico já chegou a situações em que categorizar o outro é quase um ato bem recebido pelo divino, uma exigência de se destacar o "nós" certo do "outro" corrompido. Da ala underground, sai-se mais termos de zombaria às atitudes dos evangélicos. Já do outro lado, encabelado por teólogos, cientistas e sociólogos religiosos, presencia-se um sistema de classificação ao qual se classifica cada fração religiosa mediante a sua semelhança com outros movimentos históricos. Assim, o termo 
"neoanabatista", cunhado pelo bispo anglicano Robinson Cavalcanti $(\mathrm{PE})^{14}$, gerou polêmica nas mídias cristãs brasileiras por fazer menção ao caráter disruptivo das novas comunidades de perfil juvenil, pós-moderno e cosmopolita.

Robinson destaca cinco elementos que confirma a "anabatistização" do protestantismo Latino-amaricano: 1) a apostasia da Igreja; 2) o restauracionismo; 3) o presentismo; 4) uma eclesiologia dualista e minimalista; 5) e a iconoclastia. Descontando o último item, já que o que se verifica é uma recelebração dos símbolos religiosos e dos ritos de cultuação ${ }^{15}$.

A ideia de que vivemos numa era pós-cristã (KIMBALL, 2008), em outras palavras, um momento histórico na qual o cristianismo não é mais a pedra angular da sociedade, ditando normas, regras e formas de vida para os grupos. Hoje, diante de mundo (pós)secular, o cristianismo tornou-se mais uma religião dentre outras. A laicidade do Estado-nação moderno, além de uma série de mecanismos e processo em vigor desde o século XIX, impede que 0 cristianismo seja a ponta de lança única das democracias ocidentais urbanas. O espírito pós-cristão é partilhado por todos que acham que vivemos a radicalização da crítica à Igreja ocidental e a adesão aos modos de vida do extramuros protestante-evangélico. No ambiente underground, a sensação de perda espiritual e dos laços socioculturais é enorme. Tal sentimento é expresso no recente encontro "global" que será promovido pelo Tribal Generation. O Tribal é uma agência missionária ligada à Igreja Sal da Terra (MG), liderada pelo pastor Olgálvaro Bastos Júnior, e que, assim como outros ministérios como a Avalanche (ES), o Underfaith (SP) e o Verbalizando (RJ), propõe soluções para evitar o esfacelamento total do cristianismo evangélico por meio da construção de novas pontes entre os jovens undergrounds e de outros nichos alternativos, e os familiares protestantes e pentecostais desconectados da cultura secular.

\footnotetext{
${ }^{14}<$ http://www.ultimato.com.br/revista/artigos/327/brasil-um-protestantismo-neoanabatista $>$ Acessado em: 12 dez. 2010.

${ }^{15} \mathrm{O}$ melhor exemplo é a produção estética presente na comunidade Metanóia (RJ) e na Caverna do Rock (MG), ambas ligadas à cena underground do heavy metal. Em trabalho anterior (CARDOSO, 2011), tentei enfatizar a dimensão estética e simbólica da produção do território metanoiano, que leva a uma reeducação do jovem com relação à experienciação do sagrado e aos gestos, falas e atitudes que fazem do culto no Metanóia um ritual peculiar.
} 


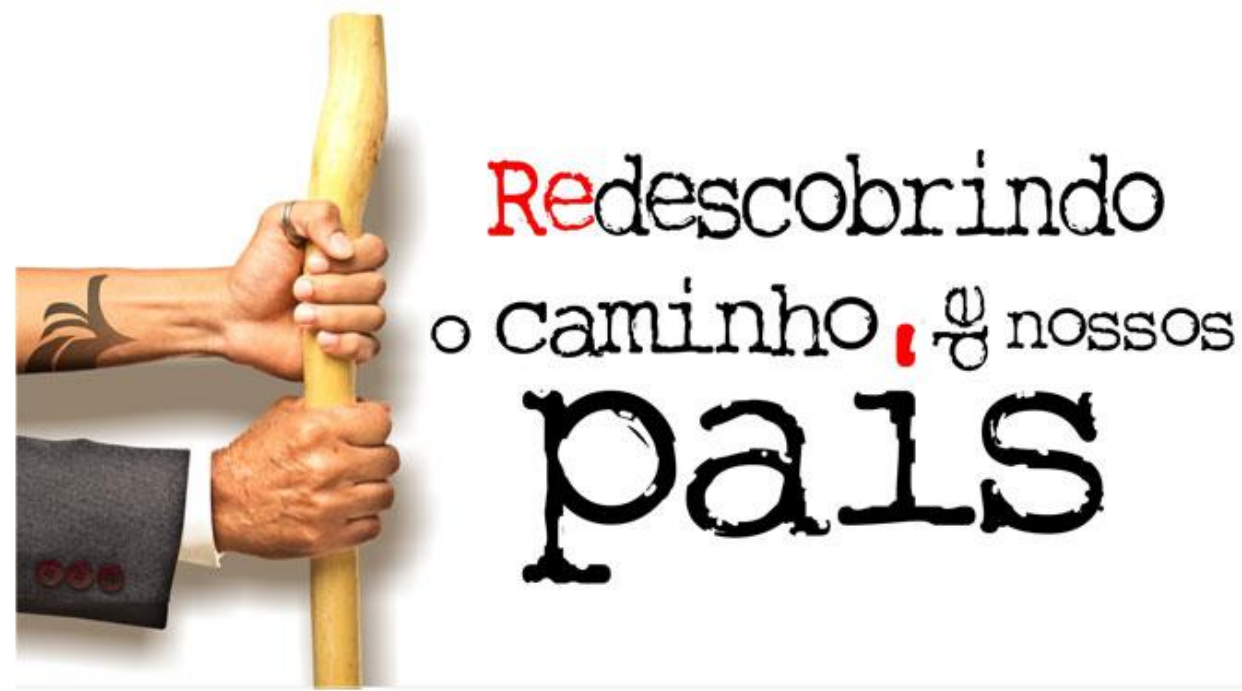

Imagem 3: Slogan do Encontro Global do Tribal Generation 2012, em Uberlândia (MG).

Fonte:<http://www.tribalgeneration.org/prt/conteudo.php?url=lernoticias\&id=780> Acessado em: 15 abr. 2012

Chegar a uma conciliação é adentrar no que cada espaço religioso tem de bom para oferecer ao outro. Criar encontros para que todos possam estar juntos e estabelecer motivações e disposições dentro de uma ótica cristocêntrica é a finalidade das novas mobilizações pela integração das comunidades cristãs. É um papel difícil, e todos estão cientes disso, dado o vício denominacionalista que domina a mente dos evangélicos. São poucos que conseguem trilhar o caminho entre a liturgia de sua igreja e a causa maior perseguida por todos que professam a mesma fé. O desafio é encontrar uma agenda comum para todos.

Os lugares religiosos tomaram tal dimensão de complexidade $\mathrm{e}$ diferenciação que, dificilmente, uma agenda comum pode ser produzida, ao menos em nível nacional e regional. Cada denominação aqui exposta está entranhada em rituais, conexões e compromissos que fogem a qualquer tipo de diálogo intercâmbio simbólico entre igrejas, e muito menos a possibilidade de diálogo inter-religioso. Mas como alguns teólogos e cientistas já alertaram, o mais irônico desse ambiente é o quanto de abertura essas mesmas denominações apresentam em relação à secularidade e à cultura midiática. 
Igrejas e mais igrejas surgiram nesse movimento de capilarização da religiosidade dentro da sociedade secular ${ }^{16}$. Uma estratégia territorial meritória que, seguindo os passos dos antigos evangélicos, consiste em fincar templos onde ainda não fora propagado o Evangelho e harmonizar (e romantizar, no caso dos pentecostais e neopentecostais) a relação entre a conservação da fé plena e os ganhos econômicos gerados numa sociedade desigual e injusta.

Enfim, esta perspectiva de senso comum que o underground cristão tenta imprimir junto às outras vertentes, coloca diante de nós uma geograficidade radical da ação coletiva que só poderá ser compreendida se justapusermos os três naipes de abordagem humana em Geografia (humana, humanística e cultural) para não em dois erros epistemológicos: 1) a análise empirista: contenta-se em fixar onde está o espaço sagrado e onde se situam os espaços profanos (ROSENDAHL, 1999); 2) o método construtivista: parte de matrizes racionalistas de construção do sagrado (MENEZES, 2003). Para o geógrafo tanto das vertentes humana, humanística ou cultural, importa que se leve em conta a reflexividade do pesquisador na interação com os interlocutores; e que se trate minuciosamente a questão da fé individual e sua concatenação com a mediação sociocultural, o sistema de crença, ou ainda, a(s) comunidade(s) confessionais que vão balizando o sujeito ao longo da sua trajetória religiosa e intramundana. Envolto nessas coisas, relações e processos, estão os lugares em que as comunidades se estabelecem e a eles dão significados e um olhar prático; as paisagens que desafiam o envolvimento do religioso com os ambientes natural e cultural; e o território e territorialidade, matrizes de fundação das religiões e religiosidades por ser a expressão geográfica do poder (SACK, 1986).

Tal aporte geográfico traz à baila a religiosidade do sujeito, entendida numa perspectiva simmeliana como sendo "uma função caracteristicamente humana que só pode se completar na interioridade mais íntima do indivíduo" (PIERUCCI, 2010) e os mecanismos de pertença religiosa e filiação comunitária que faz das pessoas indivíduos enredados em relações de poder

\footnotetext{
${ }^{16} \mathrm{O}$ exemplo mais concreto desse fenômeno é a Assembléia de Deus Vitória em Cristo, nova sucursal da maior instituição pentecostal brasileira tutelada pelo carismático pastor Silas Malafaia. Ver: <http://www.advitoriaemcristo.org/siteEdit/site/advec/inicial.cfm> Acessado em: 5 ago. 2011.
} 
(FOUCAULT, 1979) e fazedores de projetos para satisfazer o self (BRUSEKE, $\mathrm{s} / \mathrm{d})$.

\section{Fechando com mais interrogações...}

Underground cristão, um conceito indefinido, borrado e insubordinável: cada vez que tentamos descrevê-lo, é como tentar entender o jovemadolescente e sua ânsia de fugir da pressão estrutural via adesão a objetos, grupo de par e forma de agir que, ilusoriamente, Ihe dá a sensação de estar fora do "Sistema". Perscrutar o underground cristão é enveredar pela contingente trama dos relacionamentos, pertenças, interesses e combinações juvenis que jazem pulverizados na cena religiosa e nos múltiplos contextos da vida urbana. Territórios e mais territórios em disputa, ideologias em formação e guerra pela defesa dos símbolos autênticos, são as regras de formação das redes de afinidade juvenil, e as comunidades eclesiais, agências missionárias e outras formas de pertencimento ao underground cristão não escapam disso.

Mas ele tem um duplo papel: de funcionalidade e de troca simbólica. Serve para consolidar as práticas dos nativos do submundo cristão urbano. E ao mesmo tempo, é usado também para destacar um campo estético e midiático que agrega redes de afinidade dos mais variados gêneros. Do "metalismo" ao feminismo, da Caverna de Adulão (MG) ao Sabaoth (AC), do pastor death metal Batista (Crash Church) ao mano rapper Jonathan Híbrido (Pingo d'água), a palavra de ordem (divina) será sempre: do it yourself - um tributo à saudosa atitude dos punks setentistas.

Como fruto de um momento histórico da qual os protagonismos juvenis insurgem em todos os setores da sociedade brasileira, o underground cristão consiste na versão cristão-religiosa do movimento contracultural dos anos 1980, que engendrou uma série de subgêneros musicais tais como o heavy metal, death metal, gótico, hip-hop, e revisitou outros "antigos" como o punk e o rock progressivo.

Com a atmosfera de "movimento sem rumo", o protagonismo dos jovens undergrounds merece uma atenção minuciosa. Sua dinamicidade é o que faz o 
movimento se manter enquanto manifestação estética de cunho afirmativo, uma alternativa às formas hegemônicas do cristianismo que não dialogam com as mídias e juventudes emergentes. O underground cristão e a Igreja emergente são indícios fenomênicos de uma condição pós-moderna da qual as instituições cristãs legais não podem mais fugir: precisam rever permanentemente os seus princípios, dogmas, liturgia e missiologia que se superpõem e determinam as hierarquias e o funcionamento da ecclesia. Nesse burburinho social, as novas religiosidades e comunidades artísticas e eclesiásticas só refletem a sede de protagonismo estético do jovem embrenhado nas estruturas de consumo cultural e exposição midiática.

No âmbito acadêmico, discute-se muito o juízo das religiões, mas pouca atenção é prestada ao que move a pessoa religiosa em sua ascese cotidiana (principalmente o trabalho) e na peregrinação em busca de refrigério espiritual, gozo temporário (semelhante ao do turista) e/ou um significado último. É o multivíduo (CANEVACCI, 2005) fazedor de mundos de significado que está no cerne da questão religiosa, da constituição da religiosidade enquanto modo primário de vivência dos humanos em sociedade por meio da aceitação da existência de coisas, fenômenos, sistemas de linhagem e hierarquias que se situam para além das determinações materiais, engajando explicações de ordem metafísica, extra e sobrenatural.

Entender os motivos e implicações dessas novas comunidades confessionais é entender a nova dinâmica religiosa impregnada nas juventudes urbanas agora cosmopolitizadas e estetizadas, ativas nos circuitos de lazer e cultura da cidade e nos processos educativos e culturais extraoficiais que permitem um maior intercâmbio sociocultural e, por consequência, religioso, ratificando a metáfora da antropóloga Leila Amaral (2000) de que as religiosidades novaeristas são, em essência, um "carnaval da alma", e os jovens, o seu principal veículo de divulgação e expressão concreta de que as religiões e religiosidades, definitivamente, estão em um estado de mutação nunca antes visto na modernidade, tornando-as, definitivamente, pós-modernas na sua dimensão ontológica. 
Certos de que essas transformações obrigarão o campo evangélico a rever suas práticas rituais, doutrinárias, missiológicas e sociais, então cabe, em primeiro lugar, elaborar uma cartografia das mudanças na juventude contemporânea e a relação desta com as instituições evangélicas. E o segundo passo é entender o porquê de alguns jovens cristãos, inserido no mundo globalizado e atento às mudanças culturais, ruma para outras formas de vivenciar o sagrado e construir relacionamentos, digamos, mais "pessoalizados" que resultam na tênue, porém contínua, evasão de jovens das igrejas evangélicas, no posterior aumento de evangélicos não-praticantes ${ }^{17}$, e no alastramento de práticas mágico-religiosas e de comunidades neo eclesiais que buscam o rompimento doutrinário (teológico), paisagístico (estético, geográfico) e geracional (sociológico) com tudo aquilo que atrapalhe ou impeça a realização de seus interesses religiosos no contexto em que atuam.

\section{Referências Bibliográficas}

AMARAL, L. Carnaval da alma: comunidade, essência e sincretismo na Nova Era. Petrópolis: Vozes, 2000.

ANDERSON, Benedict. Comunidades Imaginadas. São Paulo: Companhia das Letras, 1987.

BIRCHAL, F. F. S. Nova Era: uma manifestação de fé da contemporaneidade. Horizonte. n. 9. v. 5. dez. 2006. p. 97-105. Disponível em: $<$ http://www.sumarios.org/sites/default/files/pdfs/28728 3804.PDF> Acessado em: 10/11/2010.

BÍBLIA SAGRADA. Bíblia do ministro com concordância: nova versão internacional. São Paulo: Vida, 2007.

BRUSEKE, F. J. Uma vida de exercícios: a antropotécnica de Peter Sloterdijk. Revista Brasileira de Ciências Sociais. n. 75. v. 26. Disponível em: <http://www.scielo.br/pdf/rbcsoc/v26n75/10.pdf> Acessado em: 25/02/2012.

CANEVACCI, M. Culturas eXtremas. Rio de Janeiro: DP\&A, 2005.

CARDOSO, D. S. Underground cristão: a construção geográfica de uma cena religiosa jovem alternativa. Porto Alegre: Liro, 2011.

CARSON, D. A. Igreja emergente: o movimento e suas implicações. São Paulo: Vida Nova, 2010.

\footnotetext{
17 Conforme diagnóstico de sociólogos e cientistas da religião, e corroborado pelos atuais dados do IBGE (Censo 2010) com relação à filiação religiosa do brasileiro.
} 
CUNHA, M. N. Explosão gospel: um olhas das ciências humanas sobre o cenário evangélico brasileiro. São Paulo: Mauad, 2007.

FOUCAULT, M. Microfísica do poder. Rio de Janeiro: Graal, 1979.

GUERRIERO, S. Novos movimentos religiosos: o quadro brasileiro. São

Paulo: Paulinas, 2006.

GUMBRECHT, H. U. Corpo e forma: ensaios para um campo nãohermenêutico. Rio de Janeiro: EDUERJ, 1998.

HARVEY, D. Condição pós-moderna: uma investigação sobre as origens da mudança cultural. São Paulo: Loyola, 1992.

JUNGBLUT, A. L. A salvação pelo Rock: sobre a "cena underground" dos jovens evangélicos no Brasil. Religião \& Sociedade. n. 2. v. 27. ago. 2007. Rio de Janeiro. p. 144-162.

KIMBALL, D. A igreja emergente: cristianismo clássico para as novas gerações. São Paulo: Vida, 2008.

MAFRA, C. Os evangélicos. Rio de Janeiro: Jorge Zahar Ed., 2001.

MARTELLI, S. A religião na sociedade pós-moderna. São Paulo: Paulinas, 1995.

MENEZES, R. C. A dinâmica do sagrado: rituais, sociabilidade e santidade num Convento do Rio de Janeiro. Rio de Janeiro: Relume Dumará, 2004.

MONDADA, L.; SÖDERSTRÖM, O. Do texto à interação: percurso através da geografia cultural contemporânea. In: CORREAA, R. L.; ROSENDAHL, Z.

Paisagens, textos e identidade. Rio de Janeiro: EDUERJ, 2004. p. 133-156.

NOVAES, Regina. Os jovens, os ventos secularizantes e o espírito do tempo. In: TEIXEIRA, F., MENEZES, R. As religiões do Brasil: continuidades e rupturas. Petrópolis: Vozes, 2006. p. 135-160.

OLIVEIRA, C. D. M. Turismo Religioso. São Paulo: Aleph, 2004.

OTTO, R. O Sagrado: Sobre o irracional na idéia do Divino e sua relação com o irracional. Lisboa: Edições 70, 1992.

PIERUCCI, A. F. Resenha. SIMMEL, G. Religião - ensaios, vol. 1. São Paulo: Olho d’Água, 2010. ISBN 978-85-7642-018-7. 148 p. Disponível em: $<$ http://www.pucsp.br/rever/rv4 2010/r pierucci.htm> Acessado em: 12/02/2012.

PINTO, F. S. Radicalmente santos: o rock'n'roll e o underground na produção da pertença religiosa entre jovens. Proa. v. 1. n. 1. ago. 2009. Disponível em: $<$ http://www.ifch.unicamp.br/proa/artigos/artigoflavia.htm> Acessado em: 12/10/2010.

RODRIGUES, F. L. O rock na evangelização. Rio de Janeiro: MK Ed., 2006. ROSENDAHL, Z. A identidade religiosa na perspectiva geográfica: os lugares sagrados. In: MANOEL, I. A.; ANDRADE, S. R. (Org.). Identidades religiosas. Franca: UNESP-FHDSS/Civitas Ed., 2008a. p. 75-90. 
A dimensão do lugar sagrado: ratificando o domínio da emoção e do sentimento no ser-no-mundo. In: OLIVEIRA, M. P; COELHO, M. C. N.; CORREAA, A. M. O Brasil, A América Latina e o mundo: espacialidades contemporâneas. Rio de Janeiro: Lamparina/FAPERJ/ANPEGE, 2008b. p. 331338.

. Hierópolis: o sagrado e o urbano. Rio de Janeiro: EDUERJ, 1999.

SACK, R. Human Territoriality: its theory and history. Cambridge: Cambridge University Press, 1986.

SANTOS, B. S. A crítica da razão indolente: contra o desperdício da experiência. São Paulo: Cortez, 2001.

SANTOS, M. G. M. P. Conhecimento geográfico e peregrinações: contributo para uma abordagem teórica. In: ROSENDAHL, Z. (Org.). Trilhas do sagrado. Rio de Janeiro: EDUERJ, 2010. p. 145-187.

SANTOS, M. Modo de produção técnico-científico e diferenciação espacial. Revista Território. ano 4. n. 6. jan/jul. UFRJ, 1999. p. 5-20. Disponível em: $<$ http://www.revistaterritorio.com.br/pdf/06 2 santos.pdf> Acessado em: 20/02/2012.

SILVA, G. A Igreja precisa voltar a ser protestante. Tribal Generation Magazine. ano 2. n. 2. mai. 2008. Uberlândia. p. 6-7.

SOUZA, R. C. Discursos e práticas fundamentalistas na Igreja Presbiteriana do Brasil. Revista Brasileira de História das Religiões - ANPUH. n. 3. v. 1. jan. 2009.Disponível em: <http://www.dhi.uem.br/gtreligiao/pub.html>, Acessado em: 20/01/2008.

VARELA, F. R. El mito de la cultura juvenil. Última Década. Valparaíso, n. 28, p. 79-90, jul. 2008.

VELHO, O. A orientalização do Ocidente: comentários a um texto de Colin Campbell. Religião e Sociedade. n. 18. v. 1. Rio de Janeiro: ISER, 1997. p. 22-47.

WEBER, M. Ética protestante e o espírito do capitalismo. São Paulo: Martin Claret, 2002. 